\title{
Autonomous Generated Income of Three Levels of Government and Money Supply in a Democratic Administration: The Case Study of Nigeria
}

\section{Cordelia Onyinyechi Omodero}

\author{
PhD, ACA., Department of Accounting, \\ College of Management Sciences, \\ Michael Okpara University of Agriculture \\ Umudike, Umuahia, Abia State, Nigeria
}

Doi: $10.2478 / m j s s-2019-0045$

\begin{abstract}
The study provides statistical proof of the influence of autonomous generated income of the three levels of government on money supply in the present day democratic administration in Nigeria. The study uses ex post facto research design and annual time series data ranging from 2000-2017. The data are obtained from CBN Statistical Bulletin 2017 edition and CBN Annual Reports and Ordinary Least Squares technique is employed to analyze them with Statistical Package for Social Sciences (SPSS) version 20. The findings reveal that Federal Government Independent Revenue (FGIR) and State government Independent Revenue (SGIR) impact on money supply positively and significantly while the Local Government Independent Revenue has insignificant positive impact on money supply. The policy implication of the results is that government revenue under the autonomous control of the three levels of government in Nigeria has a lot of influence on money circulating in the economy and therefore, stringent monetary policies should be applied to regulate it in order to prevent inflationary economic situation in the country.
\end{abstract}

Keywords: Money supply, autonomous generated income, three levels of government, Nigeria

\section{Introduction}

Money characterizes conventional medium of exchange in a nation. Accordingly, money supply represents the total currency in circulation in an economy which includes the money in the hand of individuals and the demand deposits in Deposit Money Banks and other financial institutions which can easily be converted into cash for business transactions. In other words, money supply is the total amount of monetary assets obtainable in an economy at a definite time. This can be more explained to include currency in circulations and demand deposits of financial institutions. Currency refers to coins and paper money issued by the government and the banks, while effective money consists of currency and demand deposits (Agarwal, 2018). Chen (2018) submits that money supply is the entire stock of currency and other liquid instruments flowing in an economy at a definite time period which includes cash, coins and balances kept in savings and current accounts. Money supply in Nigeria encompasses narrow money (M1) and broad money (M2). Narrow money is the total sum of money in circulation and the amount of money lodged in Deposit Money Banks in the country. Broad money includes narrow money and foreign denominated deposits (CBN, 2006).

Many countries carry out proper analysis of money supply through their central banks which also do regular publication of these pieces of information to guide the financial information users and other economic and financial analysts. For instance, the Federal Reserve in the United States measures and publishes the total amount of M1 and M2 money supply online and in newspapers 
on a weekly and monthly basis (Chen, 2018). Money supply (M2) in Pakistan is recorded, reported, analyzed and published by the State Bank of Pakistan (Ihsan \& Anjum, 2013). In Nigeria, the Central Bank of Nigeria (CBN) publishes quarterly economic report that provides the breakdown of M1 and M2 status as part of its monetary policy report. However, the amount of money in circulation in a country influences the amount of public revenue from national budgets (Bunescu, Mihaiu \& Comaniciu, 2011).

The purpose of monetary policy is to keep prices of goods and services as well as the exchange rates at equilibrium in an economy. The policy instruments deployed by the Central Bank of Nigeria to achieve this objective are the Monetary Policy Rate (MPR) and interventions such as: open market operations (OMO), discount window operations, cash reserve ratio (CRR), liquidity ratio (LR) and foreign exchange Net Open Position (NOP) limit (CBN, 2018). MPR is the major tool used by $C B N$ to regulate the course of interest rates and anchor inflation anticipations in the economy. OMO helps in liquidity management through the sale of $\mathrm{CBN}$ bills to the public while discount window operations serves as a liquidity management instrument used by the CBN to guarantee optimum level of money in circulation. These tools are supplemented with prudential requirements which include: cash reserve requirement (CRR), liquidity ratio (LR) and foreign exchange Net Open Position (NOP) which helps to provide restriction for Deposit Money Banks in Nigeria. However, monetary management in Nigeria is not done in isolation with primary market transactions in government securities and foreign exchange market interventions (CBN, 2018).

Revenue inflows into the public and private sectors in Nigeria tend to have a multiplier effect on the economy. When there are inflows, transaction demand for money heightens as a result, the volume of money in circulation increases (Oluseyi, Olasehinde \& Eweke, 2017). This increase has the propensity to depreciate the worth of money rapidly thereby, increasing cost of living while dwindling foreign and domestic investments in businesses (Ditimi, Keji \& Emma, 2018). This is evidenced by the swift relocation of businesses to other countries from Nigeria in the recent times. The Manufacturers Association of Nigeria (MAN) recorded about 272 firms that were forced out of business, though majorly due to foreign exchange restriction order in the country. However, Ihsan and Anjum (2013) submit that increase in money supply lead to decline in interest rates and growth in investment. Considering Pakistan economic environment, they argued that businesses flourish when there is more money in circulation as well as increase in demand for labor and capital goods.

This study is focused on Nigeria's economic environment and the target is to determine the impact of autonomous generated income of the three levels of government on money supply in this democracy dispensation in Nigeria. Previous studies in this area considered money supply and economic growth (Ihsan \& Anjum, 2013; Kipkirui, 2014; Aslam, 2016; Hussain \& Haque, 2017; Olusey et al., 2017), other scholars who attempted studies on the relationship between money supply and government revenue did not put into consideration the effect of fiscal decentralized revenue of different levels of government on money supply. Based on this premise, this study has been prompted to provide an empirical evidence in this research area.

\section{Theoretical Framework}

The theory supporting this study is the Fiscal Federation Theory established by Musgrave (1959) and Arrow (1974). The role of government in the effective management of an economy Musgrave's (1959) is motivated by the various undertakings of the public and private sectors Arrow (1974). It is within this structure that the three roles expected from the government sector emerge and they comprise: the role of government in ensuring equitable distribution of income, amending various forms of market failures, and the role of maintaining stability in the macro economy through stabilization of prices of goods and services. This study encourages the role of government in ensuring equitability and fairness in income distribution as well as stabilization of prices of goods and services which helps to keep money supply under check to avoid inflation. This could be achieved through government support of all monetary policies aimed at maintaining proper relationship between money supply and productive activities (CBN, 2016). The support of the government for monetary policies that will help to keep money supply at a balance with economic activities while ensuring that autonomous generated revenues of the three levels government in the country are well regulated. 


\section{Empirical Review}

\subsection{Money supply and economic growth}

Ihsan and Anjum (2013) assessed the impact of money supply on economic growth in Pakistan using economic indicators and data from 2000 to 2011 while employing regression model for analysis of data. The study established that money supply had insignificant negative impact on economic growth of Pakistan. Kipkirui (2014) carried out a detailed study on the effect of money supply on the gross domestic product (GDP) in Kenya from 1970-2012 using Engle and Granger co-integration test. The correlation analysis showed that money supply impacted on economic growth negatively at $5 \%$ significance level.

Aslam (2016) employed multivariate econometric technique to examine the impact of money supply on economic growth of Sri Lanka from 1959-2013. The study showed evidence that money supply had a significant positive influence on Sri Lanka economic growth. Dingela and Khobai (2017) examined the impact of money supply on economic growth in South Africa using autoregressive distributed lag technique and time series data from $1980-2016$. The study found a strong positive relationship between money supply ad economic growth in both long and short run. Oluseyi et al. (2017) employed Autoregressive Distributed Lag (ARDL) to investigate the impact of money supply on the economy of Nigeria from $1981-2015$. The findings showed that money supply had significant and positive impact on real GDP.

Hussain and Haque (2017) analyzed the association between money supply and per capita GDP growth rate in Bangladesh from 1972 - 2014. The findings revealed an existence of a significant positive relationship between money supply and economic growth in Bangladesh. Ditimi et al. (2018) used co-integration test and error correction approach to study the impact of money supply on inflation in Nigeria from 1970 - 2016. The adverse effect of inflation on the economy and over-all wellbeing of the Nigerian citizens motivated the study and the findings established that money supply is not the basic economic element that causes inflation in the country.

\subsection{Government revenue and money supply}

Haslag (1996) used cross-country data of 82 countries to investigate the response of government revenue to monetary policy in Seignorage. The data spanned from 1975 to 1993 and the variables include: revenue to GDP, real GDP per capita, inflation rate and ratio of bank reserve to deposits. The aim of the study was to establish the relationships between Seignorage revenue and two monetary policy - inflation rate and reserve requirements. From the cross-country evidence, Seignorage revenue as a proportion of GDP revealed that Seignorage revenue-to-GDP was positively correlated with reserve requirements. In other words, there was a positive association between government revenue and monetary policy in Seignorage.

Bunescu et al. (2011) investigated the relationship between government revenues and expenditures, population and money supply in 8 countries using data from 1980-2010. These countries include: Bangladesh, Botswana, Canada, Ethiopia, Iceland, Madagascar, Panama and Paraguay. Generally the study found that government revenue had strong correlation with money supply, population and government expenditure in these counties. The correlation between money supply and government revenue was quantified using Pearson's Coefficient, the values were between 0.707 and 0.992 for the countries sampled, thereby confirming a robust relationship between money supply and government revenue

Yakubu, Umar and Aminu (2014) examined the relationship between money supply and government revenue in Nigeria. The study was conducted in 2014 and using Nigeria as a study place. The research employed Autoregressive Distributed Lag (ARDL) co-integration test which is also referred to as bound test. Time series data from 1970 to 2010 were collected from CBN statistical bulletin to test long run relationship, while the short run relationship test used data for 2009 and 2010 only. The variables investigated were total government revenue and money supply. Two models were specified, thereby using both variables as dependent and independent variables in two different equations. When money supply was used as the dependent variable the results of 
the error correction model indicated that government revenue had a positive significant impact on money supply, both in the long run $(0.00<0.05)$ and in the short run $(0.00<0.05)$. On the other alternative test when government revenue was the dependent variable, there was no evidence of a long run relationship but rather a short run correlation was indicated. The study concluded that government revenue was actually a driving force for money supply in the Nigerian economy.

Omodero and Worlu (2018) used pre and post effect of monetary policy rate (MPR) adoption to examine the influence of money supply on oil revenue in Nigeria. The curiosity to know the resultant effect of change from minimum rediscount rate (MRR) to monetary policy rate (MPR) which has been in used from December 11, 2006 till this present time, prompted the research. The study established that when MRR was the baseline interest rate, money supply had significant and positive influence on oil revenue, but since the adoption of MPR which was used to replace MRR, money supply had a significant negative impact on oil revenue.

\subsection{Research gap}

The studies on money supply and economic growth have been a topical issue and scholars such as (Aslam, 2016; Hussain \& Haque, 2017; Olusey et al., 2017) found evidence that money supply had positive effect on economic growth while the studies of other scholars such as (Ihsan \& Anjum, 2013; Kipkirui, 2014) revealed that money supply had negative impact on economic growth. However, the literature review was also carried out to establish the relationship between money supply and government revenue. Scholar such as Haslag (1996) whose work was the pioneer study in this area found that monetary policy had a strong relationship with government revenue in Seignorage. Buescu et al. (2011) used 8 countries to extend the work and also found a strong positive correlation between money supply and government revenue while Yakubu et al. (2014) did same in Nigeria and the result revealed a positive relationship between government revenue and money supply in both long and short run. All the studies reviewed generalized government revenue, but this study is specifically examining the impact of autonomous generated revenue of the three levels of government in Nigeria on money supply, particularly in this era of democracy.

\section{Methodology}

This study adopts an ex-post facto research design which integrates the use of existing and secondary form of data that cannot be manipulated by the researcher. The dependent variable is Money Supply (MSS) represented by broad money (M2) in Nigeria while the independent variables include: federal government independent generated revenue (FIGR), State governments independent generated revenue (SIGR) and local governments' independent generated revenue (LIGR). The data on FIGR were extracted from Central Bank of Nigeria (CBN) annual reports as captured under the fiscal policy while the data for SIGR and LIGR were sourced from CBN Statistical Bulletin, 2017 edition. The data collected spanned from 2000-2017 and were analyzed using ordinary least squares technique with the aid of Statistical Package for Social Sciences (SPSS) version 20. All the data used were expressed in Billions of Naira.

The multiple regression model adopted for the study is:

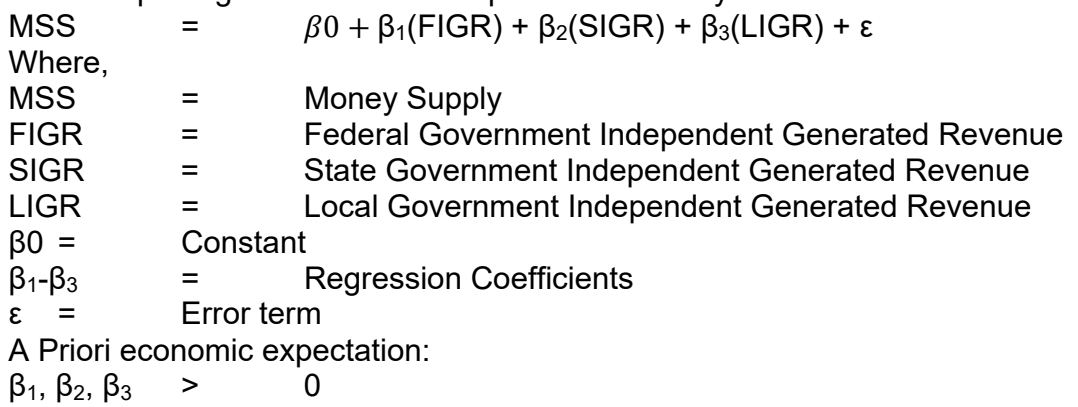

The a priori economic expectation is that FIGR, SIGR and LIGR should be greater than zero suggesting positive effect on MSS. 


\section{Data Analysis and Interpretations}

\subsection{Trend analysis of data from 2000-2017}

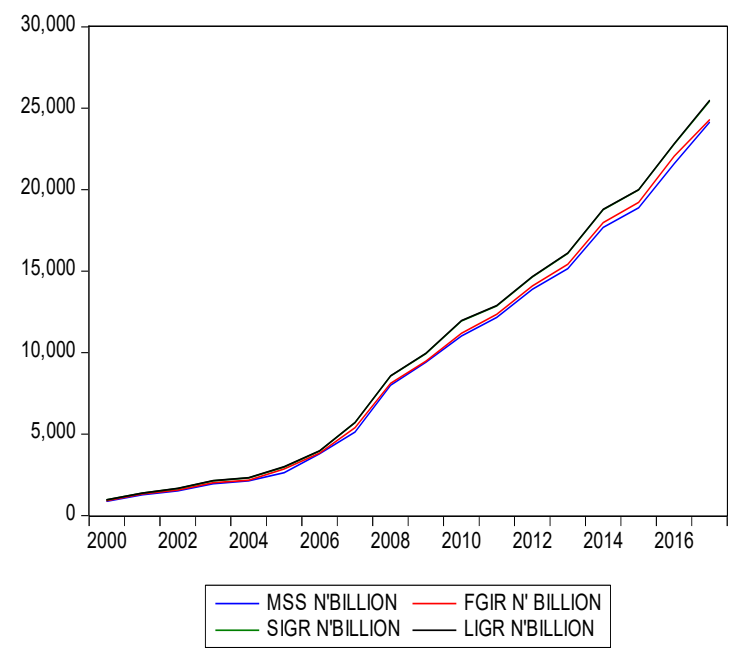

Figure 1: Movement of MSS, FIGR, SIGR and LIGR from 2000-2017 stacked in a graph.

Data Source: CBN, Statistical Bulletin, 2017 Edition and Annual Reports.

Figure I above shows that the autonomous generated income of the three levels of government in Nigeria have direct relationship with money supply. As the revenues rise or fall, money supply responds accordingly.

MSS N'BILLION

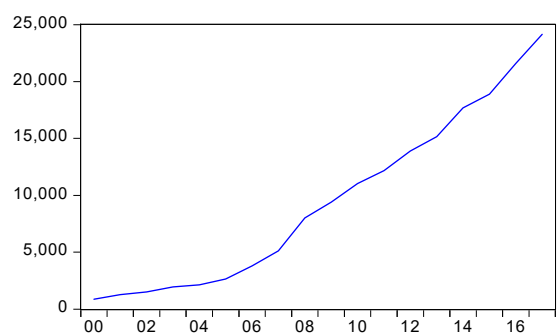

SIGR N'BILLION

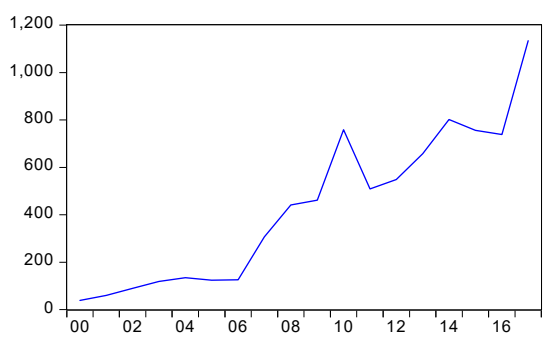

FGIR N' BILLION

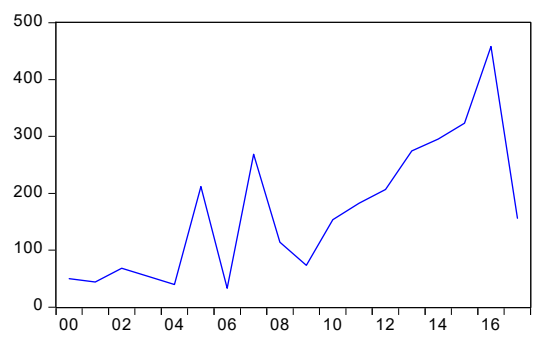

LIGR N'BILLION

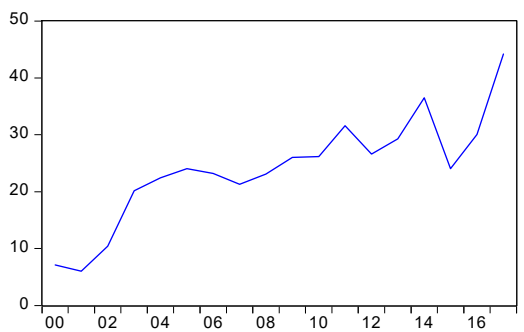

Figure 2: Movement of dependent and independent variables from 2000-2017.

Data Source: CBN, Statistical Bulletin, 2017 Edition and Annual Reports. 
Figure 2 above shows the growth of each variable used in the study from 2000-2017. It can be observed that MSS, SIGR and LIGR were all rising and in fact got to the peak in 2017 while there seemed to be a material decline in FIGR from 2015-2017. This graphical display of result shows evidence of revenue leakages, corruption and diversion of government funds for personal and selfish gains. The implication is that the federal government might not have sufficient funds to execute expenditure responsibilities if the primary cause of the fund diversion is not checked and prevented. The government will not be capable of meeting up with the routine obligations to the citizens meanwhile few individuals will be taking undue advantage of the public resources because they have access to them.

\subsection{Data analysis and interpretation of results}

Table 1: Model Summary of Results

\begin{tabular}{|c|c|c|c|c|c|}
\hline Model & $\mathrm{R}$ & $\mathrm{R}$ Square & Adjusted R Square & Std. Error of the Estimate & Durbin-Watson \\
\hline 1 & .974 & .948 & .937 & 1917.42699 & 2.194 \\
\hline
\end{tabular}

a. Predictors: (Constant), LIGR, FIGR, SIGR

b. Dependent Variable: MSS

Source: Author's computation, 2019.

Table 1 above depicts the summary results of the model used in this study. The correlation (R) value of $97.4 \%$ points out that there is significant and positive association between money supply and the autonomous generated incomes of the three levels of government in Nigeria. In a similar manner, the coefficient of determination which is the R Square indicates that FIGR, SIGR and LIGR describe up to $94.8 \%$ of the variations in MSS while the remaining $5.2 \%$ is attributable to other variables the model for this study did not capture. The Durbin-Watson of approximately 2 shows absence of autocorrelation in the regression results.

Table 2: ANOVA test of results

\begin{tabular}{|l|c|c|c|c|c|}
\hline Model & Sum of Squares & df & Mean Square & F & Sig. \\
\hline Regression & 943792279.939 & 3 & 314597426.646 & 85.569 & .000 \\
1 Residual & 51471367.519 & 14 & 3676526.251 & & \\
Total & 995263647.458 & 17 & & & \\
\hline
\end{tabular}

a. Dependent Variable: MSS

b. Predictors: (Constant), LIGR, FIGR, SIGR

Source: Author's Computation, 2019.

F-test provides statistical evidence of the joint effect of the independent variables on the dependent variable. Therefore, the F-test on Table 2 above, indicates the value of 85.569 with the p-value of 0.000 $<0.05 \%$. This value specifies that the result is statistically significant and the model is fitting for the study. However, the result further reveals that FIGR, SIGR and LIGR are affecting MSS in Nigeria collectively.

Table 3: Regression Correlations and Coefficients

\begin{tabular}{|l|c|c|c|c|c|}
\hline \multirow{2}{*}{ Model } & \multicolumn{2}{|c|}{ Unstandardized Coefficients } & Standardized Coefficients & \multirow{2}{*}{$\mathrm{t}$} & \multirow{2}{*}{ Sig. } \\
\cline { 2 - 5 } & $\mathrm{B}$ & Std. Error & Beta & -1.087 & .296 \\
\hline (Constant) & -1605.153 & 1477.108 & & 2.730 & .016 \\
FIGR & 13.377 & 4.899 & .211 & 6.534 & .000 \\
SIGR & 18.605 & 2.847 & .793 & .387 & .705 \\
\hline
\end{tabular}

a. Dependent Variable: MSS

Source: Author's Computation, 2019.

The regression result is as follows:
MSS
$(1605.153)+13.377 \mathrm{FIGR}+18.605$ SIGR + 34.484LIGR

The findings show that a unit increase in FIGR while keeping other variables constant will on the average increase the MSS by 13.377. In like manner, a unit increase in SIGR while keeping 
FIGR and LIGR constant will improve MSS by 18.605. A unit increase on LIGR while keeping other variables constant will lead to an increase in MSS by 34.484. The t-test shows the individual performance of all the predictor variables. FIGR t-test is 2.730 with p-value of $0.016<0.05 \%$, this implies that FIGR has a significant positive impact on MSS. This result agrees with the findings of (Haslag, 1996; Buescu et al., 2011; Yakubu et al., 2014). SIGR t-test is 6.534 with the p-value of $0.000<0.05 \%$, this signifies a robust and positive impact on MSS. This finding is in harmony with the studies of (Haslag, 1996; Buescu et al., 2011; Yakubu et al., 2014). LIGR t-test is 0.387 with pvalue of $0.705>0.0 .05 \%$, meaning that LIGR has an insignificant positive impact on MSS. This result conflicts with the findings of (Haslag, 1996; Buescu et al., 2011; Yakubu et al., 2014).

\section{Conclusion and Recommendations}

Money supply in an economy is very vital for the smooth running of economic activities. The revenue generated by different levels of government has so much role to play in this regard. Thus, this study provides statistical evidence that autonomous generated revenue by the different tiers of government has a unique influence on money supply in Nigeria. The federal and state governments' revenues impact on money supply positively and significantly while the local government revenue has insignificant influence on money supply. The results also show that government autonomous incomes jointly influence money supply and the relationship is very strong and positive.

Therefore, the study recommends adequate monetary policy measures that can checkmate the use of government revenue which forms part of money circulating in the country, in order to prevent inflation. The Central Bank of Nigeria can employ monetary policy measures such as sale of $\mathrm{CBN}$ Bills and discount window operation that will help control the revenue available for government to use especially at the local government levels.

\section{References}

Agarwal, M. (2018). Supply of money in an economy and its components. Available online at: http://www.economicsdiscussion.net/money/economy-money/supply-of-money-in-an-economy-and-itscomponents/8063.

Arrow, K.J. (1974). General Economic Equilibrium: Purpose, Analytic Techniques, Collective Choice. American Economic Review, American Economic Association, 64(3), 253-272.

Aslam, A.L.M. (2016). Impact of money supply on Sri Lankan Economy: An Econometric Analysis. International Letters of Social and Humanistic Sciences, 67, 11-17. DOI: 10.18052/www.scipress.com/ILSHS.67.11.

Bunescu, L., Mihaiu, D. \& Comaniciu, C. (2011). Is there a correlation between government Expenditures, population, money supply and government revenues? International Journal of Arts \& Sciences, 4(12), 241-254.

Central Bank of Nigeria (2006). What is monetary policy? CBN Monetary Policy Series, CBN/MPD/Series/01/2006.

Central Bank of Nigeria (2016). Monetary policy. CBN Education in Economic Series No. 2.

Central Bank of Nigeria (2017). CBN Statistical Bulletin. Abuja, Nigeria.

Central Bank of Nigeria (2018). The conduct of monetary policy? Available at: https://www.cbn.gov.ng/

Chen, J. (2018). Money Supply. Available at: https://www.investopedia.com/terms/m/moneysupply.asp.

Dingela, S. \& Khobai, H. (2017). Dynamic impact of money supply on economic growth in South

Africa. An ARDL Approach. Munich Personal RePEc Archive. Available at: https://mpra.ub.uni-muenchen.de/82539/.

Ditimi, A., Keji, S. \& Emma, E.O. (2018). The influence of money supply on inflation in Nigeria. Journal of Economics and Management, 31(1), 5-23. DOI: 10.22367/jem.2018.31.01

Haslag, J.H. (1996). The monetary policy effects on Seignorage revenue in a simple growth model. Research Department Working Paper 96 - 01. Federal Reserve Bank of Dallas' Historical Library.

Hussain, M.E. \& Haque, M. (2017). Empirical analysis of the relationship between money supply and per capita GDP growth rate in Bangladesh. Journal of Advances in Economics and Finance, 2(1), 54-66. DOI: 10.22606/jaef.2017.21005.

Ihsan, I. \& Anjum, S. (2013). Impact of money supply (M2) on GDP of Pakistan. Global Journal of Management and Business Research Finance, 13(6), 1-9.

Kipkirui, W.C. (2014). The effect of money supply on the gross domestic product in Kenya. M.Sc. Degree Thesis submitted to School of Business, University of Nairobi.

Musgrave, R.A. (1959). The Theory of Public Finance. McGraw Hill, New York.

Oluseyi, A.S., Olasehinde, T.J. \& Eweke, G.O. (2017). The impact of money supply on Nigeria Economy: A comparison of mixed data sampling (MIDAS) and ARDL approach. EuroEconomica, 2(36), 123-134.

Omodero, C.O. \& Worlu, C.N. (2018). Monetary policy and oil revenue in Nigeria: pre and post Effect analysis. Covenant Journal of Business \& Social Sciences (CJBSS), 9(1), 87-98.

Yakubu, M., Umar, U., \& Aminu, B.Z. (2014). Relationship between money supply and Government revenues in Nigeria. CBN Journal of Applied Statistics, 5(2), 117 - 136. 